\title{
CASE STUDY \\ Marine Mammals as Sentinel Species for Oceans and Human Health
}

\author{
BY GREGORY D. BOSSART
}

As more humans inhabit coastal regions, a global "anxiety" is developing about the health of our aquatic ecosystems. This anxiety is particularly prevalent in the United States, where more than half the population now inhabits coastal freshwater or marine ecosystems. One component of the National Oceanic and At- mospheric Administration's (NOAA's) Oceans and Human Health Initiative addresses the concept of marine sentinel organisms. As discussed by Grosell and Walsh (this issue), such sentinels are used to gain early warnings about current or potential negative trends and impacts. In turn, such indicators and warnings will permit

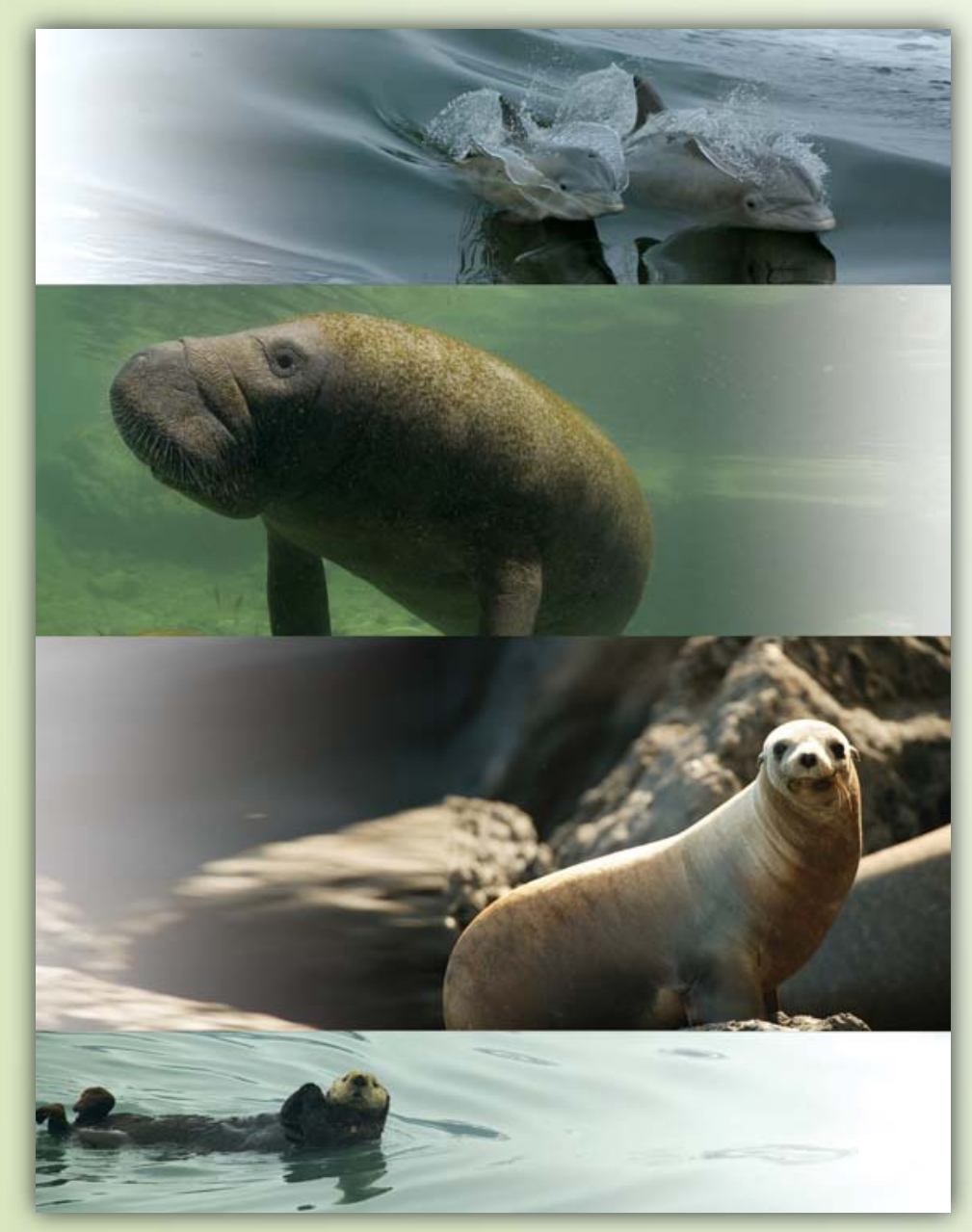

Figure 1. Marine mammals used as sentinel species of oceans and human health include (top to bottom) the Atlantic bottlenose dolphin (Tursiops truncatus), West Indian manatee (Trichechus manatus latirostris), California sea lion (Zalophus californianus) and sea otter (Enhydra lutris nereis).

us to better characterize and potentially manage negative impacts on human and animal health associated with our oceans.

Marine mammals are probably one of the best sentinel organisms in aquatic and coastal environments because many species have long life spans, feed at a high trophic level, and have extensive fat stores that can serve as depots for anthropogenic toxins (Reddy et al., 2001; Wells et al, 2004). Additionally, marine mammals are conspicuous and charismatic megafauna that elicit strong human emotions and are thus more likely to be observed (Bossart, 1999). As such, health maladies that impact these species may make humans more likely to pay attention to deteriorating ocean health issues. Virtually all threats to marine mammals are ultimately related to the population size, growth rate, and the consumption patterns and behaviors of humans (Marine Mammal Commission, 2004). Therefore, it is in our own best interest to determine what marine mammals may be telling us about their own health that could potentially impact our own well being. The following examples illustrate the diversity of marine mammal sentinels and processes currently being monitored.

\section{INFECTIOUS DISEASES}

Marine mammal sentinel species for ocean health include the Californian sea lion (Zalophus californianus), Atlantic bottlenose dolphin (Tursiops truncatus), southern sea otter (Enhydra lutris nereis), bowhead whale (Balaena mysticetus), polar bear (Ursus maritimus), and the endangered West Indian manatee (Trichechus manatus latirostris) (Figure 1). For example, approximately 20 percent of sexually mature stranded California sea lions have an unusually high incidence of a newly described 
urogenital cancer. This cancer is associated with a novel herpes virus and exposure to anthropogenic contaminants (such as PCBs and DDTs) that persist in the sea lion's feeding grounds (King et al., 2002; Ylitalo et al., 2005). More genetically inbred sea lions, and those with a specific major histocompatibility complex (MHC) genotype, are more likely to develop cancer. These data suggest that interactions occur among genes, toxins, and viruses, resulting in cancer in this ubiquitous marine mammal that shares its coastal California environment with humans (Acevedo-Whitehouse et al., 2003; Ylitalo et al., 2005).

Toxoplasmosis is a sometimes fatal human and animal disease caused by infection with Toxoplasma gondii, a single-celled protozoal parasite. Toxoplasmosis is a major cause of mortality among southern sea otters. For example, a recent seroprevalence analysis showed toxoplasmosis infection in 52 percent of beachcast sea otters and in 38 percent in live sea otters sampled along the California coast (Miller et al., 2002). As nearshore predators, otters serve as sentinels of protozoal pathogen flow into the marine environment because they share the same environment and consume some of the same foods as humans. Investigation into the processes promoting T. gondii infections in sea otters provides a better understanding of terrestrial parasite flow and the emergence of disease at the interface among wildlife, domestic animals, and humans (Conrad et al., 2006).

\section{ANTHROPOGENIC POLLUTANTS}

Polar bears, bowhead whales, and bottlenose dolphins can serve as sentinels for coastal ecosystem pollution. Organohalogen and heavymetal contaminant biomagnification among polar bears and bowhead whales may reflect Arctic Ocean health (Woshner et al., 2001; Kucklick et al., 2002; Hoekstra et al., 2003a; Hoekstra et al., 2003b; Hoekstra et al., 2003c; Hoekstra et al., 2005; O'Hara et al., 2005). Furthermore, for Alaskan residents dependent upon marine resources, a clear human con- nection exists with polar bear health because both humans and polar bears feed on similar prey, and the polar bear itself is consumed by humans.

Bottlenose dolphins reside in ocean, coastal, and estuarine communities, and are exposed to a variety of persistent pollutants (Stein et al., 2003; Houde et al., 2005). Additionally, bottlenose dolphins and manatees harbor diseases important to ecosystem health, as well as human health (Bossart et al., 2003b; Bossart et al., 2004; Bossart et al., 2005; Reif et al., in press). Recent pathologic studies of dolphins and manatees indicate, for example, that the emerging or resurging infectious and neoplastic diseases may reflect environmental distress, and these diseases have direct or indirect relevance to human health (Bossart et al., 1997; Miller et al., 2001; Bossart et al., 2002a; Bossart et al., 2003a; Rehtanz, et al., 2005) (Figure 2).

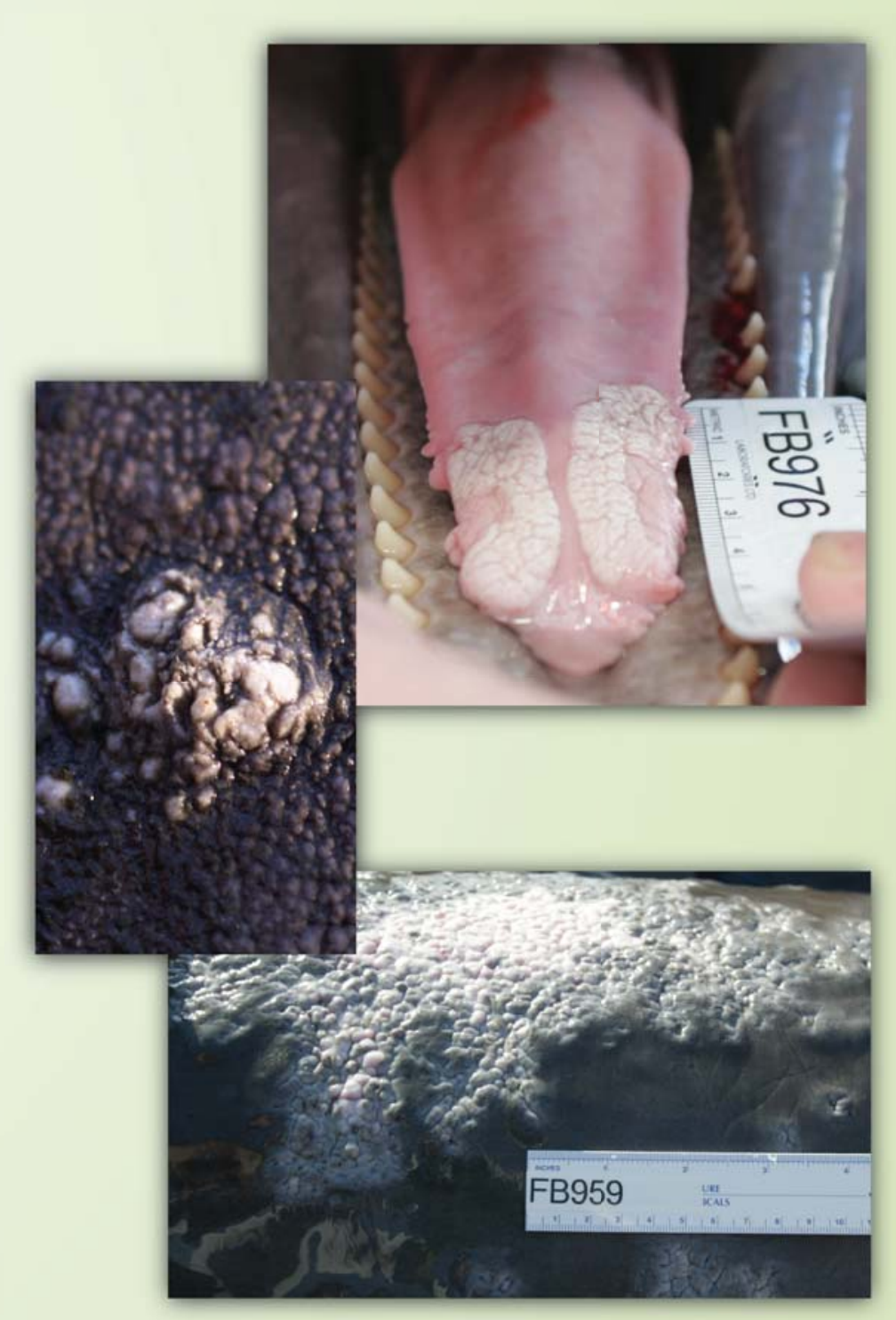

Figure 2. Infectious and neoplastic emerging disease in marine mammals may have ecosystem and public health significance. Examples of these diseases are (top to bottom) oral sessile papillomas associated with a novel herpesvirus in bottlenose dolphins; cutaneous papillomas caused by a novel papillomavirus in manatees; and cutaneous lobomycosis, a zoonotic fungal disease of bottlenose dolphins. 
HARMFUL ALGAL BLOOMS (HABS)

\section{AND THEIR TOXINS}

$\mathrm{HABs}$ and the potent biotoxins they elaborate are incriminated in mass mortalities of dol-

phins, sea lions, and manatees (Gulland, 2000;

Bossart, 2001; Bossart et al., 2002b; Flewelling et al., 2005) (Figure 3). The range of biotoxins produced by $\mathrm{HABs}$ is extensive and associated with many human $\mathrm{HAB}$ illnesses. HAB biotoxins include the following: brevetoxins, the cause of neurotoxic shellfish poisoning; saxitoxins, the cause of paralytic shellfish poisoning; okadaic acid, the cause of diarrhetic shellfish poisoning; azaspiracid, the cause of azaspiracid shellfish

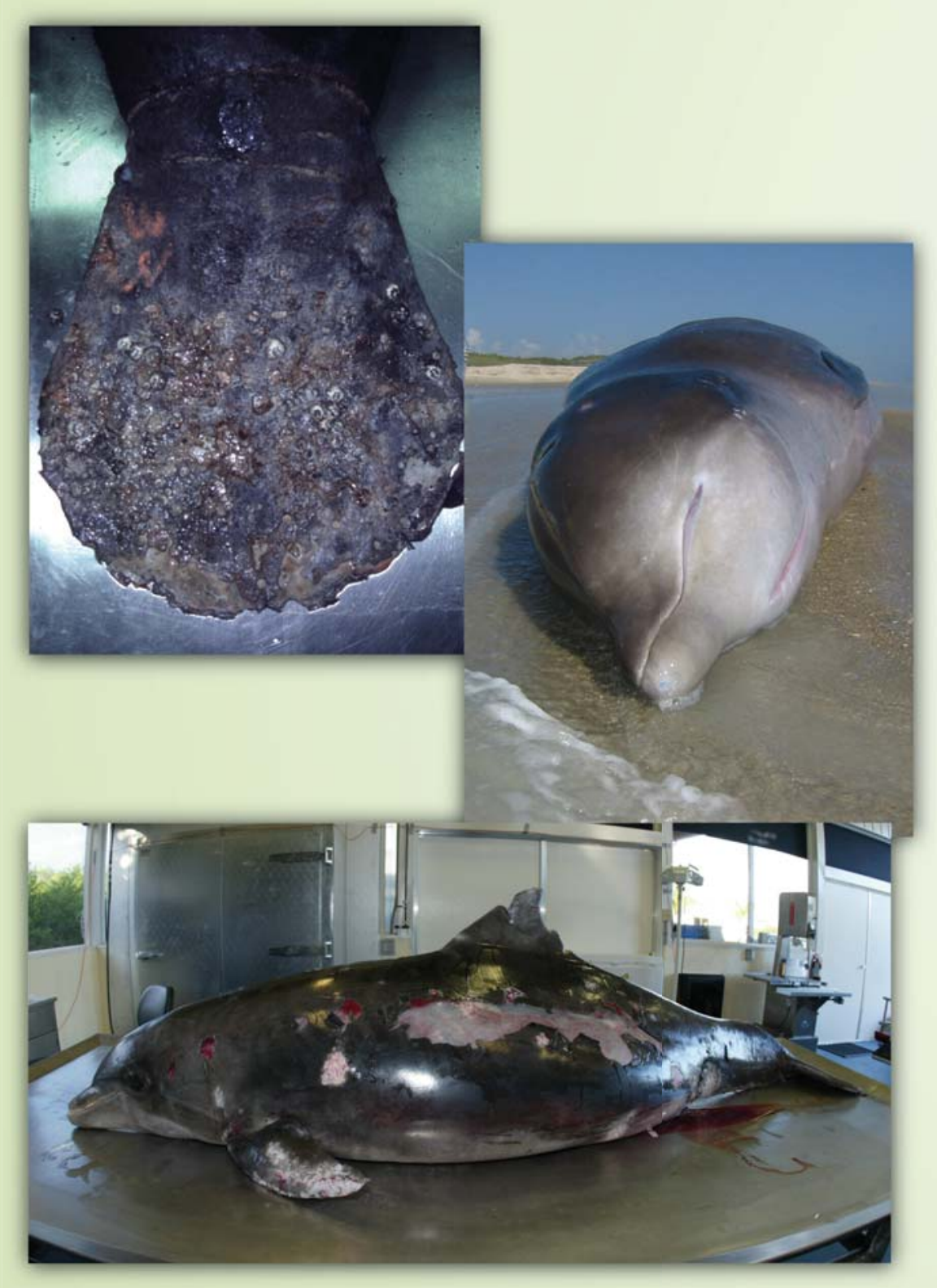

Figure 3. Harmful algal bloom biotoxins poison dolphins and manatees causing singular and mass strandings and sometimes large epizootics (top to bottom, singular stranded manatee with suspected brevetoxicois and skin lesions, stranded beaked whale [Mesoplodon europaeus] and bottlenose dolphin). Harmful algal bloom biotoxins impact dolphins and manatees via ingestion and/or inhalation of toxins similar to humans. poisoning; and numerous others (Landsberg, 2002). The HAB problem is significant, growing worldwide, and poses a major threat to human and ecosystem health (Kirkpatrick et al., 2004; Glibert et al., 2005). Fortunately, marine mammals appear to be good sentinels for the ecosystem and public health effects of HABs. For example, the inhalational route of brevetoxin exposure appears to be unique among marine mammals in manatees, but it is shared with humans (Bossart et al., 1998).

It is clear that new challenges and opportunities for interdisciplinary research exist for utilizing marine mammal sentinel species for oceans and human health. The value of this approach will expand as new additions are made to the list of marine mammal species and processes being monitored. In addition, this approach provides a new avenue for better understanding the intersection between intriguing ecosystem and public health issues.

\section{ACKNOWLEDGEMENTS}

The author gratefully acknowledges manuscript critical review and editorial advice by Dr. R.H. Defran, and special thanks to Sarah Bechdel and Elisabeth Howells for technical assistance.

\section{REFERENCES}

Acevedo-Whitehouse, K., F.M.D. Gulland, D. Greig, and W. Amos. 2003. Disease susceptibility in California sea lions. Nature 422:35.

Bossart, G.D., R. Ewing, A.J. Herron, C. Cray, S. Decker, J. Alexander, and N.H. Altman. 1997. Immunoblastic malignant lymphoma in dolphins: Ultrastructural and immunohistochemical features. Journal of Veterinary Diagnostic Investigation 9:454-458.

Bossart, G.D., D.G. Baden, R.Y. Ewing, B. Roberts, and S.D.Wright. 1998. Brevetoxicosis in manatees (Trichechus manatus latirostris) from the 1996 epizootic: Gross, histologic and immunohistochemical features. Toxicologic Pathology 26:276-282.

Bossart, G.D. 1999. The Florida manatee: on the verge of extinction? Journal of the American Veterinary Medical Association 214:10-15.

Bossart, G.D. 2001. Manatees. Pp. 939-960 in: Marine Mammal Medicine, L. Dierauf and F. Gulland, eds. CRC Press, Boca Raton, FL.

Bossart, G.D., R. Ewing, M. Lowe, M. Sweat, S. Decker, C. Walsh, S. Ghim, and A.B. Jenson. 2002a. Viral papillomatosis in Florida manatees (Trichechus manatus latirostris). Experimental and Molecular Pathology 
72:37-48.

Bossart, G.D., D.G. Baden, R.Y. Ewing, and S.D. Wright. 2002b. Manatees and brevetoxicosis. Pp. 205-212 in Molecular and Cell Biology of Marine Mammals, C. Pfeiffer, ed. Krieger Publishing Co., Melbourne, FL.

Bossart, G.D., R. Meisner, S.A. Rommel, S. Ghim, and A.B. Jenson. 2003a. Pathological features of the Florida manatee cold stress syndrome. Aquatic Mammals 29(1):9-17.

Bossart, G.D., R. Meisner, R. Varela, M. Mazzoil, S. McCulloch, D. Kilpatrick, R. Friday, E. Murdoch, B. Mase, and R.H. Defran. 2003b. Pathologic findings in stranded Atlantic bottlenose dolphins (Tursiops truncatus) from the Indian River Lagoon, Florida. Florida Scientist 66(3):226-238.

Bossart, G.D., R. Meisner, S.A. Rommel, J.A. Lightsey, R.A. Varela, and R.H. Defran. 2004. Pathologic findings in Florida manatees (Trichechus manatus latirostris). Aquatic Mammals 30(3):434-440.

Bossart, G.D., S. Ghim, M. Rehtanz, J. Goldstein, R. Varela, R. Ewing, P. Fair, R. Lenzi, B. Joseph, C. Hicks, L. Schneider, C.J. McKinnie, J.S. Reif, R. Sanchez, A. Lopez, S. Novoa, J. Bernal, M. Goretti, M. Rodriguez, R.H. Defran, and A.B. Jenson. 2005. Orogenital neoplasia in Atlantic bottlenose dolphins (Tursiops truncatus). Aquatic Mammals 31(4):473-480.

Conrad, P., C. Kreuder, J. Mazet, H. Dabritz, M. Miller, D. Jessup, F. Gulland, M. Grigg, and E. James. 2006. Linkages between cats, run-off and brain disease in sea otters. Paper presented at the Symposium, Marine Mammals on the Frontline: Indicators for Ocean and Human Health. American Association for the Advancement of Science, Annual Meeting, St. Louis, MO, February 18, 2006. American Association for the Advancement of Science, Washington, D.C.

Flewelling, L.J., J.P. Naar, J.P. Abbott, D.G. Baden, N.B. Barros, G.D. Bossart, M.D. Bottein, D.G. Hammond, E.M. Haubold, C.A. Heil, M.S. Henry, H.M. Jacocks, T.A. Leighfield, R.H. Pierce, T.D. Pitchford, S.A. Rommel, P.S. Scott, K.A. Steidinger, E.W. Truby, F.M. VanDolah, and J.H. Landsberg. 2005. Red tides and marine mammal mortalities. Nature 435:755-756.

Glibert, P.M., D.M. Anderson, P. Gentien, E. Graneli, and K.G. Sellner. 2005. The global, complex phenomena of harmful algal blooms. Oceanography 18(2):137-147.

Gulland, F. 2000. Domoic acid toxicity in California sea lions (Zalophus californianus) stranded along the central California coast, May-October 1998. Report to the National Marine Fisheries Service Working Group on Unusual Marine Mammal Mortality Events. NOAA Technical Memorandium NMFSOPR-17. U.S. Department of Commerce, National Oceanic and Atmospheric Administration, Washington, D.C., 45 pp.

Hoekstra, P.F., T.M. O'Hara, A.T. Fisk, K. Borga, K.R. Solomon, and D.C.G. Muir. 2003a. Trophic transfer of persistent organochlorine contaminants (OCs) within an Arctic marine food web from the southern Beaufort-Chukchi Seas. Environmental Pollution
124:509-522.

Hoekstra, P.F., T. M. O'Hara, H. Karlsson, K.R. Solomon, and D.C.G. Muir. 2003b. Enantiomer-specific biomagnification of $\alpha$-hexachlorocyclohexane and selected chiral chlordane-related compounds within an Arctic marine food web. Environmental Toxicology and Chemistry 22:2,482-2,491.

Hoekstra, P.F., R.J. Letcher, T.M. O'Hara, S.M. Backus, K.R. Solomon, and D.C.G. Muir. 2003c. Hydroxylated and methylsulfone-containing metabolites of polychlorinated biphenyls in the plasma and blubber of bowhead whales (Balaena mysticetus). Environmental Toxicology and Chemistry 22:2,650-2,658.

Hoekstra, P.F., T.M. O'Hara, S.M. Backus, C. Hanns, and D.C.G. Muir. 2005. Concentrations of persistent organochlorine contaminants in bowhead whale tissues and other biota from northern Alaska: Implications for human exposure from a subsistence diet. Environmental Research 98:329-340.

Houde, M., R. Wells, P. Fair, G.D. Bossart, A. Hohn, T. Rowles, J. Sweeney, K. Solomon, and D. Muir. 2005. Polyfluoroalkyl compounds in free-ranging bottlenose dolphins (Tursiops truncatus) from the Gulf of Mexico and Atlantic Ocean. Environmental Science \& Technology 39:6,591-6,598.

King, D.P., M.C. Hure, T. Goldstein, B.M. Aldridge, F.M.D. Gulland, J.T. Saliki, E.L. Buckles, L.J. Lowenstine, and J.L. Stott. 2002. Otarine herpesvirus-1: A novel gammaherpesvirus associated with urogenital carcinoma in California sea lions (Zalophus californianus). Veterinary Microbiology 2277:1-7.

Kirkpatrick, B., L.E. Fleming, D. Squicciarini, L.C. Backer, R. Clark, W. Abraham, J. Benson, Y.S. Cheng, D. Johnson, R. Pierce, J. Zaias, G. Bossart, and D.G. Baden. 2004. Literature Review of Florida Red Tide: Implications for Human Health Effects. Harmful Algae 3(2):99-115.

Kucklick, J.R., W.D.J. Struntz, P.R. Becker, G.W. York, T.M. O'Hara, and J.E. Bohonowych. 2002. Persistent organochlorine pollutants in ringed seals and polar bears collected from northern Alaska. The Science of the Total Environment 287:45-59.

Landsberg, J.H. 2002. The effects of harmful algal blooms on aquatic organisms. Reviews in Fisheries Science 10:113-390.

Marine Mammal Commission. 2004. Annual Report to Congress. Marine Mammal Commission, Bethesda, MD.

Miller, D., R.Y. Ewing, and G.D. Bossart. 2001. Emerging and resurging diseases. Pp.15-25 in Marine Mammal Medicine, L. Dierauf and F. Gulland, eds. CRC Press, Boca Raton, FL.

Miller, M.A., I.A. Gardner, C. Kreuder, D.M. Paradies, K.R. Worcester, D.A. Jessup, E. Todd, M.D. Harris, J.A. Ames, A.E. Packham, and P.A. Conrad. 2002. Coastal freshwater runoff is a risk factor for Toxoplasma gondii infection of southern sea otters (Enhydra lutris nereis). International Journal for Parasitology 32:997-1,006.

O'Hara, T. M., P.F. Hoekstra, C. Hanns, S.M. Backus, and D.C.G. Muir. 2005. Concentrations of selected persistent organochlorine contaminants in storebought foods from northern Alaska. International Journal of Circumpolar Health 64:303-313.

Reddy, M.L., L.A. Dierauf, and F.M.D. Gulland. 2001. Marine mammals as sentinels of ocean health. Pp. 3-13 in Marine Mammal Medicine, Second Edition, L.A. Dierauf and F.M.D. Gulland, eds. CRC Press, Boca Raton, FL.

Rehtanz, M., S.J. Ghim, A. Rector, M. van Ranst, A.B. Jenson, and G.D. Bossart. 2005. Isolation of a novel papillomavirus (PV) from a genital lesion of a bottlenose dolphin: Tursiops truncatus Papillomavirus Type 2. In: Proceedings from the $36^{\text {th }}$ Annual Conference of the International Association for Aquatic Animal Medicine, May 14-18, 2005, Seward, AK, 122.

Reif, J.S., M. Mazzoil, S.D. McCulloch, R.A. Varela, J.D. Goldstein, P.A. Fair, and G.D. Bossart. In press. Lobomycosis in Atlantic bottlenose dolphins (Tursiops truncatus) from the Indian River Lagoon, Florida. Journal of the American Veterinary Medical Association.

Stein, J.E., K.L. Tilbury, J.P. Meador, J. Gorelzany, G.A.J. Worthy, and M.M. Krahn. 2003. Ecotoxicological investigations of bottlenose dolphin (Tursiops truncatus) strandings: Accumulation of persistent organic chemicals and metals. Pp. 458-485 in Toxicology of Marine Mammals, J.G. Vos, G.D. Bossart, M. Fournier, and T.J. O'Shea, eds. Taylor \& Francis, London, United Kingdom.

Wells, R.S., H.L. Rhinehart, L.J. Hansen, J.C. Sweeney, F.I. Townsend, R. Stone, D. Casper, M.D. Scott, A.A. Hohn, and T.K. Rowles. 2004. Bottlenose dolphins as marine ecosystem sentinels: Developing a health monitoring system. Ecohealth 1:246-254.

Woshner, V.M., T.M. O'Hara, G.R. Bratton, and V.R. Beasley. 2001. Concentrations and interactions of selected essential and non-essential elements in ringed seals and polar bears of Arctic Alaska. Journal of Wildlife Diseases 37:711-721.

Ylitalo, G.M., J.E. Stein, T. Hom, L.L. Johnson, K.L. Tilbury, A.J. Hall, T. Rowles, D. Greig, L.J. Lowenstine, and F.M.D. Gulland. 2005. The role of organochlorines in cancer-associated mortality in California sea lions (Zalophus californianus). Marine Pollution Bulletin 50:30-39.

GREGORY D. BOSSART (gbossart@hboi.edu) is Director and Head of Pathology, Division of Marine Mammal Research and Conservation, Harbor Branch Oceanographic Institution, Ft. Pierce, FL, USA. 